\title{
Discussion on Raymond Williams' Methodology of Drama Criticism
}

\author{
Jinsong Zhang* \\ Nanjing Forestry University, Nanjing, Jiangsu Province, China \\ *Corresponding author: Jinsong Zhang, 2268945437@qq.com
}

\begin{abstract}
Raymond Williams is one of the representative figures of British cultural Marxism and British cultural research. His cultural research, especially mass culture research, focuses on literary criticism. Among them, drama criticism is one of Williams' most important forms of cultural criticism methodology. Williams' drama criticism is based on drama history criticism. Through the historical analysis of drama content and form as well as the synchronic analysis of modern drama in different historical periods, including the ongoing drama history, Williams proposed the notion of "structures of feeling." The emergence of this concept opened up the social critical dimension of Williams' drama criticism. Drama criticism has become a window for examining, analyzing, and grasping the current social emotional structure or social culture. Furthermore, by implanting tragic plots in the drama, a potential practical strategy of social and cultural revolution can be realized.
\end{abstract}

Keywords: Drama criticism; History of drama; Cultural selection; Emotional structure; Common culture

Publication date: October 2021; Online publication: October 29, 2021

\section{Introduction}

Raymond Williams is a representative figure of postwar British cultural Marxism and one of the founders of British cultural research. He put forward the concept of cultural materialism, analyzed and criticized British culture, especially mass culture, on basis of this theory, which had a far-reaching impact on contemporary western Marxist cultural research and mass culture research.

\section{Drama criticism as an important form of Williams' cultural criticism methodology}

\subsection{Literary criticism as the core of Williams' cultural criticism methodology}

Williams' social theory mainly involves the development of British culture. It analyzes and criticizes the development process of social culture in the form of literature, drama, and novels. From the chronological order of Williams' research on social problems, Williams mainly focused on the social phenomena from the Industrial Revolution in Great Britain to the end of the Second World War. He focused on the life emotions of the general public, headed by the working class in this period. Through the study of these emotions, Williams emphasized the incompleteness of the Industrial Revolution. He believes that the Industrial Revolution is only one of the countless human revolutions. The end of the Industrial Revolution in Britain does not mean the cease of this social revolution. Williams believes that the British revolution should be continuous. In this long-term revolution, both the Industrial Revolution and Class Revolution are important components. Through these long-term revolutionary forms, the people have formed the spirit of struggle and the spirit of social culture. In the common practice of communication and revolution of mankind, these cultural and spiritual elements have formed a "common culture." 


\subsection{The evaluation model emphasizes results over development}

At present, the traditional reward and punishment model is still used in the evaluation of college teachers in China, whereby the results of teacher evaluation are used as an important basis for appointment, promotion, and professional title evaluation. This static evaluation model forces teachers to be in a passive position, leading to a difficulty to develop a sense of participation among teachers, affecting their autonomy and enthusiasm, as well as disregarding their original subject position in evaluation. The reward and punishment model undoubtedly plays a certain incentive role for teachers, but this material reward and external return forcibly bind teachers, reduce teachers to the utilitarian satisfaction of simply pursuing external benefits, and lose the internal incentive function of the teacher evaluation system.

\subsection{Drama criticism as an important form of Williams' literary criticism methodology}

Williams believes that drama is the most social of all art formsbecause drama is both literary and theatrical ${ }^{[1]}$. On the one hand, as a literary form, its content and style change according to the development of social history. Its complex and changeable forms of expression are closer to people's life than other literary forms. The creation of drama is based on the society. It organizes the popular language at a particular time into a logical and meaningful text through oral expression, thus increasing the performance effect of the work. On the other hand, the script expresses the logic and meaning vividly through the self-play of the actors. In this way, they are better understood by people both in terms of the communication mode and the acceptance mode. Therefore, as a methodological form of cultural criticism, drama criticism can effectively analyze and explain the process of social and cultural development, especially the contradictions in these processes.

\section{Drama history criticism as the basis of Williams' drama criticism}

Similar to his study of other literary forms, Williams' study of drama criticism mainly focused on modern dramas after the Industrial Revolution, or dramas from Ibsen to the mid-20th century. However, due to the influence of Marxist historical materialism and its social analysis methods, Williams' drama criticism has never left the history of drama development, which means that Williams' drama criticism is based on drama history criticism. Therefore, Williams discovered the evolution of modern drama itself and launched his criticism of modern drama. Through the criticism of drama history, the form and content of drama are connected with the social life at that time, so as to find the complex relationship between drama form change and social change.

\subsection{Religious mysticism and the rise of moral drama in the Middle Ages}

Williams first investigated the formation and development of medieval dramas. He believes that on the surface, medieval English dramas are directly related to social forms. The dramas during this period have a unique style, in which most dramas are derived from religious content, such as worship rituals and various complex doctrines. These original dramas were mainly used to preach and explain various religious concepts in the early stage of formation because at that time, many believers could not read religious books that were written in Latin. Thereafter, drama became the main way of performance in the hymn parade. In the process of performance, mystery and fantasy dramas were the main contents. Classic religious stories such as The Last Supper, The Fall of Satan, and The Last Judgment were staged repeatedly. Williams found that in addition to the close relationship between medieval drama and social and religious organizations, there is also another feature; that is, moral drama is integrated more into religious drama. According to Williams, this kind of moral drama is extracted from the emotional model of religious drama. The difference between this kind of moral drama and mystery drama or fantasy drama is that it does not completely come from religious doctrines or stories, but from people's thinking in regard to their existence in the society at 
that time.

\subsection{Development of modern capitalism and the class struggle consciousness of drama content}

Williams then analyzed the development process of British drama at the end of the 15th century and concluded that new changes have taken place in the form and content of dramas at the end of the 15th century; popular religious stories and plots have declined as a whole, and these old forms have been forgotten by drama performers. During this period, the Tudor society became the backdrop for the development of dramas. This is because the form of drama organization undertaken by trade unions in the past can no longer meet the needs and popularity of ordinary people, and in the new social environment, commercial interests have gradually become a hot topic in the society; such commercial interests have become a part of the social structure during the establishment and development of the Tudor Dynasty. In that way, the common people, the drama, and the Tudors formed an organic system under the demand of this common commercial interest. Especially in the mid-16th century, the performance of drama was no longer expressed by means of parade in the street as before but rehearsed and performed in a fixed place. At that time, the earliest theaters in Britain began to appear. Williams believes that the development tension in the history of drama does not come from the structural changes of the script, but from the economic and political development as well as the changes in the social background. He believes that the theater was established because the drama staffs were controlled by speculators during that period. In the suburbs of London, these speculators began to build their own drama business circle. In order to gain more economic and policy support, speculators tend to associate the content of the drama with the achievements of the Queen Elizabeth era, so as to spread the lifestyle and spirit of the royal nobles at that time, thus gaining the protection of the royal members. However, this phenomenon did not last for long in the history of British drama. With the expansion of Puritanism, the national character of dramas became disorganized. The audience to such private theaters represented by speculators became smaller and smaller because the social environment at that time was constantly changing. Probably because in the last fifteen years of Queen Elizabeth's reign and the first few years of James I's reign, the conditions under which the drama used to express the mainstream of national life have been in a state of high tension; this state of tension is corresponding to the contradictions that soon broke out in the open political realm ${ }^{[2]}$. Williams analyzed this phenomenon and argued that the royal family and members of the aristocracy in the past could no longer protect the theaters run by speculators in the circumstances of that time because the aristocracy had become distant from the lives of ordinary people, and the gap was increasing. At this time, the feature of the script was no longer blindly promoting the magnificence of the royal family but turned to the contradiction of real life. At that time, the bourgeoisie not only became the spearhead, but also formed the scale of development; thereby, the contradiction between the bourgeoisie and the feudal aristocracy became a class contradiction.

\section{Emotional structure as the methodological logic of Williams' drama criticism}

Through the diachronic analysis of drama, that is, the criticism of drama history, Williams investigated the complex relationship between the formal change of drama and social change, summarized the characteristics of different development stages, as well as dealt with the history of drama by stages or "slicing" on that basis. At the same time, through synchronic analysis and abstract summary of the content and form of modern drama in different historical periods, Williams proved the general feature of drama in different development stages - emotional structure. Hence, the evolution and development process of drama history is compared to the concrete presentation form of social emotional structure changes in different periods. This metonymy also makes drama criticism transform from a form of literary criticism to a form 
of cultural criticism, opens the theoretical horizon of Williams' cultural research, and ensues drama criticism as a form of cultural criticism.

\subsection{Emotional structure as a methodological summary of drama history criticism and modern drama criticism}

Williams' concept of "structures of feeling" is based on the historical analysis and synchronic analysis of drama. In other words, emotional structure is a theoretical summary of the criticism of drama history and different times, especially modern drama. On the one hand, Williams linked the forms and contents of dramas in different periods with the social life of that time through his criticism of the history of dramas, and then was able to analyze the social phenomena behind dramas, especially the social status and role of the middle class in modern Britain. However, this was not all of his purpose. Williams wanted to obtain an emotional factor of the general public through the analysis of the drama with social reality as the background, so as to grasp the social consciousness and psychological demand of the people more widely as well as to understand the development trend of mass culture through the study of the psychological changes among people. After systematically summarizing these dramas and their phenomena in real social life, Williams put forward the concept of "structures of feeling." He believes that when studying the historical, cultural, and social phenomena of a period, it is possible to more or less accurately reproduce the material life and social organization as well as reconstruct the dominant concept to a great extent. It is not necessary to discuss which is the decisive aspect of the complex totality. It may be very useful to connect a work with the observed totality, but even if people have decomposed it into isolated parts, there are always some factors that hinders the finding of the external corresponding parts; this is a common sense, and it is necessary to recognize this in the analysis. This factor is known as the sensory structure of a period, which can be recognized only through the experience of a whole art ${ }^{[3]}$. Williams desired to accurately share the whole process of social life in the form of cultural development through his summarized notion, "structures of feeling." Williams believes that the particularity of this emotional structure can reflect the life feelings of the people in a certain period. These feelings can dominate and influence people's ideas in the process of cultural creation.

\subsection{Emotional structure opens the social and cultural criticism dimension of drama criticism}

With the introduction of the concept of emotional structure, the complex relationship between the changes of the form and content of drama and social life can be grasped. The history of drama is no longer the history of evolution of drama content and form, but the changing process of emotional structure that determines the drama content and form in different periods. Here, the emotional structure has become the essence to determine the drama structure. The literary form of drama has become the expression of the emotional structure and a specific way of reflecting the world. As an ongoing drama history, the modern drama form has become the expression form of the emotional structure of the society at that time. Furthermore, the research on the form, structure, and content of modern drama has become an important window to look into the social emotional structure at that time. The analysis and criticism of the form and content of modern drama has become the analysis and criticism of the emotional structure of this era or the culture of a period. Just as Williams described the emotional structure in The Long Revolution, "I want to use the word sensory structure to describe it: as the word 'structure' implies, it is stable and clear, but it plays a role in the most subtle and hard-to-touch part of our activities. In a sense, this sensory structure is the culture of an era: it is the special and living result of all factors in the general organization ${ }^{[4]}$." Therefore, the social and cultural criticism dimension of drama criticism can be revealed. Drama criticism is not only a pure form of literary criticism but has become an important starting point and entry point of social and 
cultural criticism.

\section{Conclusion}

In the debate with scholars with traditional cultural consciousness such as Levis, Williams has put forward a "right of choice" of culture, which encourages people to have the freedom to choose culture and create culture, thus refuting the proposition that culture is determined by historical facts. Through the study of the plots in literatures and dramas as well as people's ordinary emotions in the real society, Williams desired to share a common social and cultural thought and grasp it in the name of emotional structure; this common social and cultural thought is the social mass culture. In Williams' critical theory, literature, drama, and society have become one, mass culture has become the core of these research subjects, and cultural materialism with emotional structure as the core concept has become the theoretical basis in the research process. In this way, a Marxist cultural theory characterized by British history and culture has been formed.

\section{Disclosure statement}

The author declares that there is no conflict of interest.

\section{References}

[1] Willians R, 1964, Drama from Ibesen to Elio, Chatto and Windus, London, 14.

[2] Williams R, 2013, The Long Revolution [Ni W, Trans.], Shanghai People's Publishing House, 266.

[3] Williams R, Oromo M, 1954, Preface to Film, Film Drama, London, 21-22. Reprinted by Shu KZ: Williams R, 2011, A Theoretical Study of Cultural Materialism, Xueyuan Press, 191.

[4] Williams R, 2013, The Long Revolution [Ni W, Trans.], Shanghai People's Publishing House, 75. 